\title{
Thirty years of leatherback turtle Dermochelys coriacea nesting in Espírito Santo, Brazil, 1988-2017: reproductive biology and conservation
}

\author{
Liliana P. Colman ${ }^{1, *}$, João C. A. Thomé ${ }^{2}$, Antônio de P. Almeida ${ }^{3}$, \\ Cecília Baptistotte ${ }^{2}$, Paulo C. R. Barata ${ }^{4}$, Annette C. Broderick ${ }^{1}$, Flávia A. Ribeiro ${ }^{5}$, \\ Lucas Vila-Verde ${ }^{5}$, Brendan J. Godley ${ }^{1}$ \\ ${ }^{1}$ Centre for Ecology and Conservation, University of Exeter, Cornwall Campus, Penryn, TR10 9EZ, UK \\ ${ }^{2}$ Centro TAMAR-ICMBio, Vitória, ES, Brazil 29050-335 \\ ${ }^{3}$ ICMBio, Linhares, ES, Brazil 29900-979 \\ ${ }^{4}$ Fundação Pró-Tamar, Salvador, BA, Brazil 41185-135 \\ ${ }^{5}$ Fundação Pró-Tamar, Vitória, ES, Brazil 29050-256
}

\begin{abstract}
In the southwestern Atlantic Ocean, leatherback turtles Dermochelys coriacea are only known to regularly nest in eastern Brazil, on the coast of the state of Espírito Santo. Here, we present an analysis of the nesting ecology, population trends and conservation status of this leatherback turtle colony between 1988 and 2017. We observed an increasing, although variable, trend in the annual number of nests, with the mean increasing from 25.6 nests in the first $5 \mathrm{yr}$ of the study to 89.8 in the last 5 yr. Concurrently, there was also a significant decrease in the mean curved carapace length of the population, which we hypothesize was caused by recruitment of new females to the nesting population. Throughout the study period, nests were concentrated in the southern part of the $160 \mathrm{~km}$ long study area. No change was observed in the annual median nesting date. Mean annual hatching success was $66.0 \%$ and no significant variation in hatching success was detected after a major spill of mining tailings into the nesting area in 2015 . We postulate that local conservation actions that started in the 1980s have contributed to the gentle recovery of this population; however, given the small population size and restricted nesting geographical distribution alongside the persistence of various threats - fisheries bycatch, climate change, pollution and coastal development - this population continues to be of conservation concern.
\end{abstract}

KEY WORDS: Atlantic Ocean · Brazil · Conservation · Dermochelys coriacea $\cdot$ Leatherback turtle · Nesting biology $\cdot$ Population trend $\cdot$ Reproductive parameters

\section{INTRODUCTION}

Leatherback turtles Dermochelys coriacea are highly migratory animals, often moving vast distances between nesting and foraging habitats (James et al. 2005, Hays et al. 2006, Shillinger et al. 2008, Fossette et al. 2014, Horrocks et al. 2016). Estimating population size for widely dispersed species can be feasible if these species form seasonal aggregations, as happens with seabirds (Patterson et al. 2008, Lynch et al.

*Corresponding author: 1.p.colman@exeter.ac.uk
2010), whales (Lindsay et al. 2016) and marine turtles (Stokes et al. 2014). Marine turtles congregate during the breeding season, with individuals generally staying in inshore internesting habitats for approximately 3-4 mo, laying eggs several times on nearby nesting beaches during that period (Eckert et al. 2012). Assessments of the numbers of nests laid on the nesting beaches can then be used as an indicator of population size (Spotila et al. 1996, Gerrodette \& Taylor 1999).

(C) The authors 2019. Open Access under Creative Commons by Attribution Licence. Use, distribution and reproduction are unrestricted. Authors and original publication must be credited. 
The leatherback turtle is globally classified as Vulnerable by the International Union of Conservation of Nature (IUCN; Wallace et al. 2013b). However, the existence of distinct subpopulations (Wallace et al. 2010a) requires specific data for the assessment of their conservation status. The Southwest Atlantic Ocean subpopulation is known to regularly nest only in eastern Brazil, on the coast of the state of Espírito Santo (Thomé et al. 2007). This population, which is regionally classified as Critically Endangered by the IUCN (Wallace et al. 2013b) and listed on the Brazilian government's register of endangered species (Machado et al. 2008), is genetically distinct from others in the Atlantic (Dutton et al. 2013) and is considered a unique Regional Management Unit (Wallace et al. 2010a). Occasional leatherback nests, possibly by turtles from subpopulations other than the Southwest Atlantic Ocean one, are recorded elsewhere along the Brazilian coast (Soto et al. 1997, Barata \& Fabiano 2002, Loebmann et al. 2008, Bezerra et al. 2014, Gandu et al. 2014).

The Brazilian Sea Turtle Conservation Programme (Projeto TAMAR) started monitoring marine turtle nesting on beaches in Espírito Santo in 1982, initially on Comboios beach and gradually extending towards the northern part of the state (see Fig. 1). A previous study conducted by Thomé et al. (2007) presented the field methods used by Projeto TAMAR in the region and analysed leatherback nesting data from 1988 to 2003, suggesting that this population was experiencing an exponential increase in size.

On 5 November 2015, the study area was potentially impacted by a large-scale environmental disaster caused by the collapse of a tailing (mining waste) dam at the Fundão iron ore mine in the state of Minas Gerais, Brazil. The dam's collapse caused the death of 19 people and released an estimated 55-62 million $\mathrm{m}^{3}$ of tailings into the Doce River watershed (Fernandes et al. 2016, Marta-Almeida et al. 2016), highly impacting the riverine fauna and flora (Carmo et al. 2017). This was the largest environmental disaster ever recorded in Brazil (Marta-Almeida et al. 2016). Significant socio-environmental issues ensued, given the scale and severity of the dam's collapse. The river was loaded with toxic tailings mostly composed of Fe and other metals such as $\mathrm{Mn}, \mathrm{Cr}, \mathrm{Zn}, \mathrm{Ni}, \mathrm{Cu}, \mathrm{Pb}$ and Co (Queiroz et al. 2018), which reached the Atlantic Ocean 2 wk later in Espírito Santo, 660 km downstream from the collapsed dam, impacting estuarine, coastal and open ocean environments (Carmo et al. 2017) including the marine turtle nesting grounds analysed here (Thomé et al. 2017). We hypothesize that the contamination of the nesting grounds could have had impacts on leatherback turtle reproductive parameters such as hatchling success and total hatchling production, through the alteration of the nesting environment.

In the present study, we aimed to determine if the population trend reported by Thomé et al. (2007) has continued, and to update the monitoring results with an additional $14 \mathrm{yr}$ of data, expanding the temporal scale of the analyses to a total of 30 nesting seasons (1988-2017). The analysis of long-term data sets from conservation programmes is essential in evaluating their effectiveness. Furthermore, we aimed to investigate possible effects of the mining incident on this population as well as to address a number of priority research questions (Rees et al. 2016), including (1) estimation of the population trend, (2) analysis of reproductive parameters and (3) evaluation of the conservation situation of leatherback turtles nesting in Espírito Santo.

\section{MATERIALS AND METHODS}

\subsection{Study area}

The study area is located on the coast of Espírito Santo state in Brazil, between latitudes $19^{\circ} 50^{\prime}$ and $18^{\circ} 36^{\prime} \mathrm{S}$ (Fig. 1a). The nesting area comprises $160 \mathrm{~km}$ of high-energy dynamic beaches with coarse sand, and is influenced by the discharge from the Doce River in its southern part. The region is operationally divided into 4 sections, in a south-north direction: Comboios $(37 \mathrm{~km})$, Povoação $(39 \mathrm{~km})$, Pontal do Ipiranga $(44 \mathrm{~km})$ and Guriri $(40 \mathrm{~km})$ (Fig. 1). The entire area is divided by permanent marker posts at each $\mathrm{km}$, so the location of nests was recorded accordingly. A $15 \mathrm{~km}$ beach stretch just to the south of the Doce River mouth is located within the Comboios Biological Reserve, a protected area created by Brazilian federal law in 1984 mainly to protect the marine turtle nesting grounds and the sandy coastal ecosystem ('restinga' in Portuguese); the $22 \mathrm{~km}$ of beach further to the south are within Indigenous Lands, protected by law, with restricted access and virtually no buildings; the areas north of the Doce River are not formally designated as protected, however local, state and federal laws and environmental regulations apply to the coastal zone in the region (Thomé et al. 2007). Baptistotte et al. (2003) described the climate and vegetation in the area. In addition to the nesting of leatherback turtles, Espírito Santo is also a major nesting site in Brazil for loggerhead turtles Caretta caretta (Baptistotte et al. 2003), with approximately 

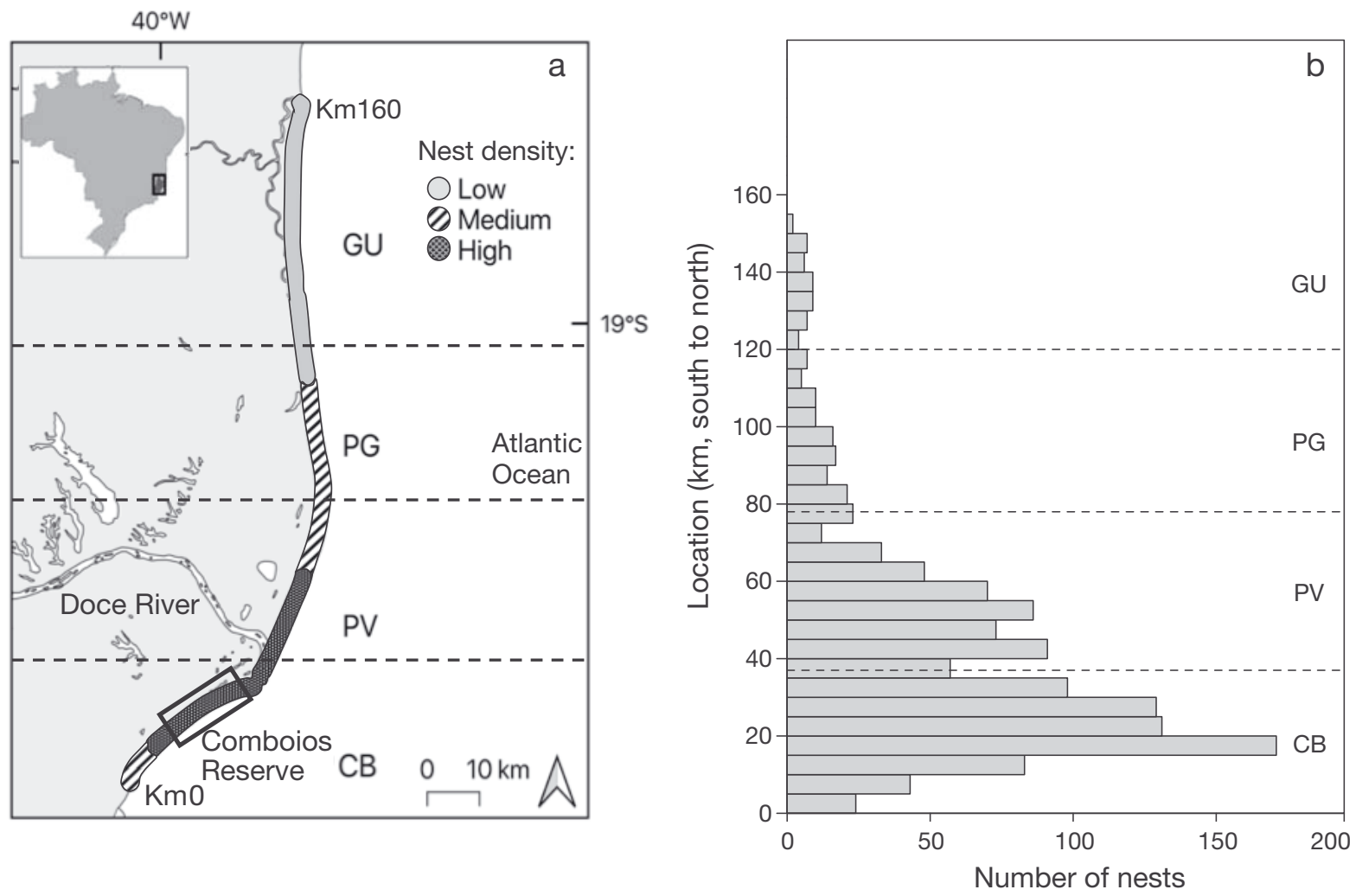

Fig. 1. (a) Leatherback turtle nesting areas in Espírito Santo, Brazil. Inset: location of Espírito Santo state in Brazil. Nest density classification (high, medium or low density) was based on the relative nest density of sixteen $10 \mathrm{~km}$ sections of the nesting area (see 'Materials and methods'). Black rectangle: limits of the Comboios Biological Reserve. (b) Spatial distribution of leatherback nests in Espírito Santo, 1988-2017 ( $\mathrm{n}=1316) ; \mathrm{km} 0$ is the southernmost point of the study area. Dashed horizontal lines: boundaries between TAMAR stations: CB: Comboios; PV: Povoação; PG: Pontal do Ipiranga; GU: Guriri. The Doce River mouth is located at the boundary between CB and PV

2500 nests recorded $\mathrm{yr}^{-1}$ in recent years (TAMAR unpubl. data). Nests of olive ridley Lepidochelys olivacea and hawksbill Eretmochelys imbricata turtles are also recorded there in small numbers (Marcovaldi \& Marcovaldi 1999).

\subsection{Temporal patterns and field methods}

The leatherback turtle nesting season typically runs from September to March. As each nesting season spans 2 calendar years, hereafter we refer to a season by the first of those 2 years, e.g. the season 2015-2016 is referred to as the 2015 season. Although TAMAR started working in Espírito Santo in 1982 , the area has only been completely monitored since 1988, thus only data from 1988 onwards were incorporated into the current analyses.

Monitoring procedures followed standard TAMAR methodology (Marcovaldi \& Marcovaldi 1999, Thomé et al. 2007). Morning patrols were conducted daily between 1 September and 31 March along the entire $160 \mathrm{~km}$ to assess nesting activity from the preceding night and to quantify the number of clutches laid. Night patrols were also undertaken opportunistically over the $30 \mathrm{~km}$ of beach between the Comboios and Povoação stations. The main reason for the unequal effort in night patrols was the high cost of maintaining this activity over such an extensive area. We used data from morning patrols to determine nest numbers and data from night patrols to gain insights into female reproductive parameters. A small proportion of nests $(2.9 \%)$ were laid in the months of April to August, but were recorded by TAMAR; these nests were included in the analyses.

Nests were located during morning patrols, marked with a numbered wooden stake and monitored during the incubation period. Nests were then excavated after the majority of hatchlings had emerged, or after $90 \mathrm{~d}$ (the longest incubation period shown for this population; Thomé et al. 2007). In 1998, 1999 and from 2008 onwards, when a crawl (a nesting emergence) was detected but a 
clutch could not be found, the entire area where the sand had been disturbed (termed a body-pit) was cordoned off. The presence of a clutch would then be confirmed later by the emergence of hatchlings. Nevertheless, $25.8 \%$ of all nesting crawls observed in 1998, 1999 and from 2008-2017 were listed as 'undetermined.' We assigned these undetermined crawls as either nests or false crawls (nesting crawls that did not result in egg deposition) based on the known percentage of all crawls that resulted in egg deposition in the 1988-1997 and 2000-2007 nesting seasons (66.0\%). Thus, for each nesting season in 1998, 1999 and from 2008-2017, we assumed that $66.0 \%$ of all undetermined crawls were actual nests, and added these to the total number of confirmed nests.

Nests that were in danger of beach erosion or tidal flooding were relocated either to more stable areas of the beach or, until 1997 in Povoação and 2000 in Comboios, to in situ hatcheries. We analysed the spatial distribution of nests based on the relative frequency of their occurrence in each $\mathrm{km}$; the spatial distribution was compared among decades through a chi-squared test for the equality of proportions (Dalgaard 2008).

\subsection{Mark-recapture}

Females were tagged on both hind flippers (Balazs 1999, Marcovaldi \& Marcovaldi 1999) using monel tags until 1994 and inconel tags after 1995 (National Band and Tag; style 681). Tag sites were checked for the presence of scars or calluses, which could indicate tag loss (Hughes 1996). Curved carapace length (CCL) was measured using a flexible measuring tape, from the centre of the nuchal notch to the posterior tip of the carapace alongside the central dorsal ridge, following the method described in Thomé et al. (2007).

Internesting intervals were calculated as the number of days between an observed egg laying and the subsequent observed egg laying (Broderick et al. 2002). Records of individuals observed nesting in different seasons were used to determine the remigration interval (number of years since the last observed nesting season). Although there is no clear record of the effort applied on night patrols across the years, they started to be conducted regularly (at least 3 times $w^{-1}$ ) from 2005 onwards, and thus we calculated female reproductive parameters (internesting and remigration intervals) only with data from 2005 onwards.

\subsection{Nest density}

We created an indicator to measure the relative importance of each section of the beach in terms of nest density. The $160 \mathrm{~km}$ study area was subdivided into 16 sections of $10 \mathrm{~km}$ each. The average annual number of nests on each section for the period 2008-2017 (the last $10 \mathrm{yr}$ of data) was calculated. Each section of the beach was then classified in terms of nest density as either high, medium or low, by locating the average annual number of nests on that section within the distribution of the 16 average numbers: high density sections were those with average annual number of nests in the top $25 \%$ of the distribution; low density sites were those in the lowest $25 \%$ of the distribution; and sites with densities between the 2 previous categories were classified as medium density (Fuentes et al. 2016).

\subsection{Hatching success}

Hatching success was calculated as the percentage of yolked eggs that produced live hatchlings, including live hatchlings encountered in the nest during excavation (Thomé et al. 2007). Nests with $0 \%$ hatching success (failed clutches) were also included in the analyses, and only in situ nests were considered. To evaluate possible effects of the mining incident on the hatching success of leatherback turtles, we analysed the 3 seasons before $(2012,2013,2014)$ and the 3 after $(2015,2016,2017)$ the event.

\subsection{Statistical analysis}

Statistical analyses were conducted using R v.3.5.1 (R Core Team 2018) applying a significance level of 0.05 . The trend in the annual number of nests was estimated using a generalised additive model (GAM) with the function 'gamm' of the R package 'mgcv' (Wood 2017). Annual variation in CCL was assessed using a local polynomial regression, by means of the R package 'locfit' (Loader 1999); for each female, only the first CCL record in each season was considered in the regression calculations. For statistical analyses concerning the CCL distribution in the whole study period (mean, SD), only the first record of each female among all seasons was considered. In the analysis of hatching success, a non-parametric Kruskal-Wallis test was used (Hollander \& Wolfe 1999). For the analysis of nesting dates, each season was considered to run between 1 August and 31 July. 
The date of each nesting event was converted to an absolute date (the time interval in days since the start of the season), and those were used to calculate the median nesting date (MND) of the season. The change in MND over the seasons was analysed by means of an ordinary least-squares linear regression (Robinson et al. 2014). A detailed description of statistical analyses is presented in the Supplement at www.int-res.com/articles/suppl/n039p147_supp.pdf.

\section{RESULTS}

\subsection{Population trend and size}

We estimate that 1608 leatherback turtle clutches were laid between 1988 and 2017. The GAM regression in Fig. 2 was significant (approximate significance of the smooth term: $F=14.71$, estimated degrees of freedom [edf] $=4.18, \mathrm{p}<0.00001$ ) and indicated a non-constant increasing trend in the annual number of nests. The mean annual number of nests over the first 5 yr (1988-1992) was 25.6 nests, while during the last 5 yr (2013-2017) it was 89.8 nests. Thus, we estimate that between 2013 and 2017 the annual nesting population consisted of between 15 and 18 females, assuming an average of 5 and 6 clutches female ${ }^{-1}$ season $^{-1}$ (Spotila et al. 1996, Eckert et al. 2012).

\subsection{Turtle tagging and CCL}

Between 1989 and 2017, 143 individual nesting females were tagged in 372 encounters (no turtles were tagged in 1988). CCL at first capture ranged from 124.7-182.0 cm (mean \pm SD: $152.9 \pm$ 10.0, $\mathrm{n}=141$ ). There was a significant decrease in CCL across the $29 \mathrm{yr}$, as no horizontal line (representing a constant CCL in the period) can be placed inside the 0.95 simultaneous confidence band in Fig. $3(\mathrm{n}=151)$. In the initial $5 \mathrm{yr}$ of the period (1989-1993), the mean CCL was $166.3 \pm 7.3 \mathrm{~cm}(\mathrm{n}=12)$, while in the last 5 yr (2013-2017) it was $149.9 \pm 9.1 \mathrm{~cm}$ (n $=49$ ). There was a sharp downward shift in the CCL distribution from 2011 onwards (Fig. 3). In the $7 \mathrm{yr}$ period 2011-2017, the estimated quantile 0.05 of the CCL distribution was $134.3 \mathrm{~cm}$, while it was $149.0 \mathrm{~cm}$ in the preceding
7 yr period (2004-2010). Fig. 3 also shows the estimated quantile 0.95 in each of these $7 \mathrm{yr}$ periods; together with the quantiles 0.05, they allow us to visualise the marked downward shift in the CCL distribution from 2011 onwards. The 2 smallest leather-

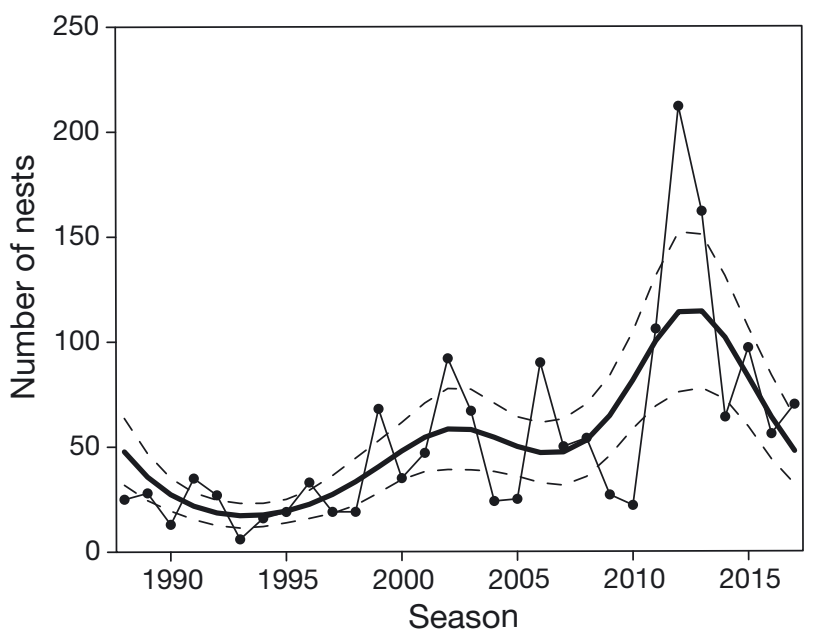

Fig. 2. Annual number of leatherback turtle nests in Espírito Santo, Brazil, 1988-2017 (1608 nests in total). The first year of each season is shown on the horizontal axis (e.g. 1995 represents the 1995-1996 season). Connected dots: raw data; solid curve: generalised additive model regression; dashed curves: approximate 0.95 pointwise confidence intervals. For full details on statistical methods see the Supplement

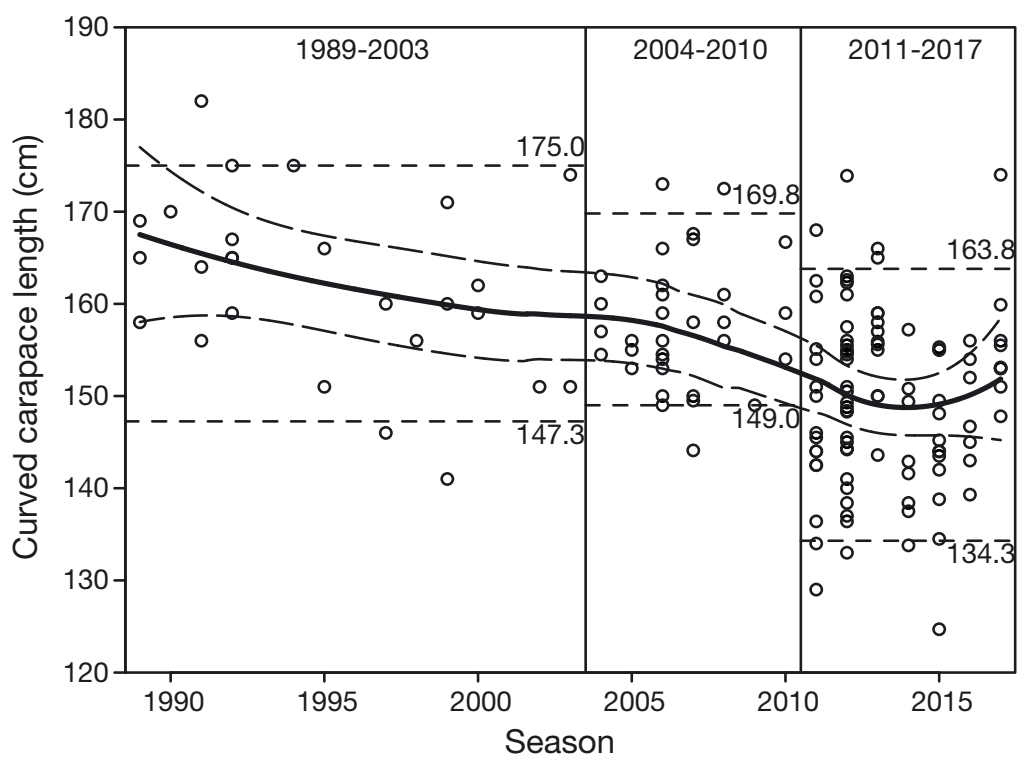

Fig. 3. Leatherback turtle curved carapace length (CCL) by nesting season, 1989-2017 ( $\mathrm{n}=151)$. Solid curve: local polynomial regression; dashed curves: 0.95 simultaneous confidence band. Vertical lines divide the overall time period into 3 smaller periods; horizontal dashed lines in each period indicate estimated 0.05 and 0.95 quantiles of the CCL distribution in the period; numerals above/below the dashed lines show the values of the quantiles. For the regression calculations, the true values of CCL and season were used. For full details on statistical methods see the Supplement 
backs ever measured while nesting in Espírito Santo were recorded in $2011(\mathrm{CCL}=129.0 \mathrm{~cm})$ and 2015 $(\mathrm{CCL}=124.7 \mathrm{~cm})$ (Fig. 3).

No leatherbacks were ever found nesting in Espírito Santo bearing tags applied elsewhere, and no leatherbacks tagged in Espírito Santo have ever been reported nesting elsewhere. Individuals bearing only a single tag accounted for $6.1 \%$ of all recaptures, which provides a lower bound for the probability of tag loss in this population, since the loss of both tags could have gone unnoticed when encountering a turtle on the beach; flipper scars suggesting that both tags had been lost were found on 1 individual bearing no tags. Leatherbacks were recaptured between 1 and 7 times in a given season; the maximum recapture distance along the beach in the same season was $65 \mathrm{~km}$ (mean: $14.1 \pm 11.0 \mathrm{~km}, \mathrm{n}=98$ ). Of the 143 females tagged, 48 (33.6\%) were never recaptured. Our annual capture rates, or proportion of nests laid within a season that could be attributed to a known female, varied between 21.9 and $53.4 \%$ during the period 2013-2017.

\subsection{Spatial distribution of nests}

Clutches were distributed across the entire region; however, there was a higher concentration in the southern part of the study area: $75.2 \%(n=651)$ of all

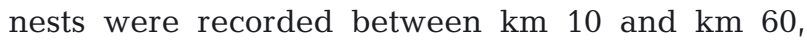
which delimit the high density nesting sites (Fig. 1). When comparing the spatial distribution among 3 decadal periods (1988-1997, $\mathrm{n}=209 ;$ 1998-2007, $\mathrm{n}=$ $456 ; 2008-2017, \mathrm{n}=651$ ), there was no significant difference in the proportion of nests located between $\mathrm{km} 10$ and 60 (high density areas) among the 3 periods $\left(\chi^{2}=2.12, \mathrm{p}=0.35\right)$. In the whole $30 \mathrm{yr}$ period, $25.1 \%$ of the total number of nests with recorded location $(n=1316)$ were located within the protected area of Comboios Biological Reserve (between $\mathrm{km} 23$ and km 36; Fig. 1b). On the north side of the Doce River, the southern part of Povoação (between $\mathrm{km} 38$ and $\mathrm{km} \mathrm{60)} \mathrm{is} \mathrm{also} \mathrm{an} \mathrm{important} \mathrm{nesting} \mathrm{area,} \mathrm{with}$ $28.3 \%$ of the total number of nests with recorded location during the $30 \mathrm{yr}$ period (Fig. 1b).

\subsection{Temporal distribution of nests}

Of the total number of nests with recorded date of nesting ( $\mathrm{n}=1325), 66.9 \%$ were laid between November and December (Fig. 4a). There was no significant trend in the annual MND over the study period $\left(\mathrm{r}^{2}=\right.$ 0.0040, $\mathrm{p}=0.741$; Fig. 4b) although the MND was highly variable among seasons, with a range of $48 \mathrm{~d}$. Much of this range can be attributed to atypically late nesting that occurred in 1990, 1994 and 2005, and early nesting in 1997 and 1998. We currently have no estimates as to whether those early and late nesting seasons could have been driven by climate factors.

\subsection{Internesting interval}

The recorded internesting intervals ranged from 8-62 d ( $\mathrm{n}=148$ intervals from 74 ind.; Fig. 5a). The multimodal pattern in Fig. 5a suggests that the internesting interval is in the range of $8-15 \mathrm{~d}$, with
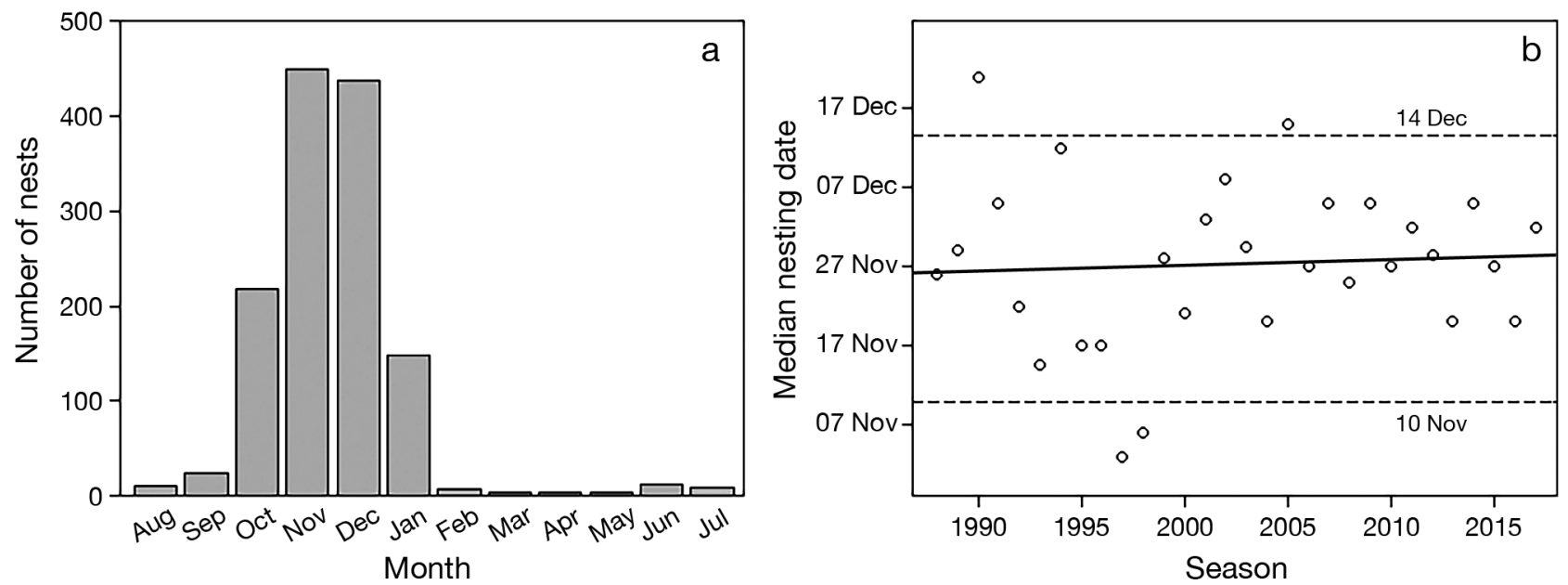

Fig. 4. (a) Number of leatherback turtle nests by month in Espírito Santo, 1988-2017 (n = 1325); (b) annual median nesting date (MND) by nesting season. Solid line: ordinary linear regression; dashed lines: estimated quantiles 0.05 and 0.95 of the MND distribution 

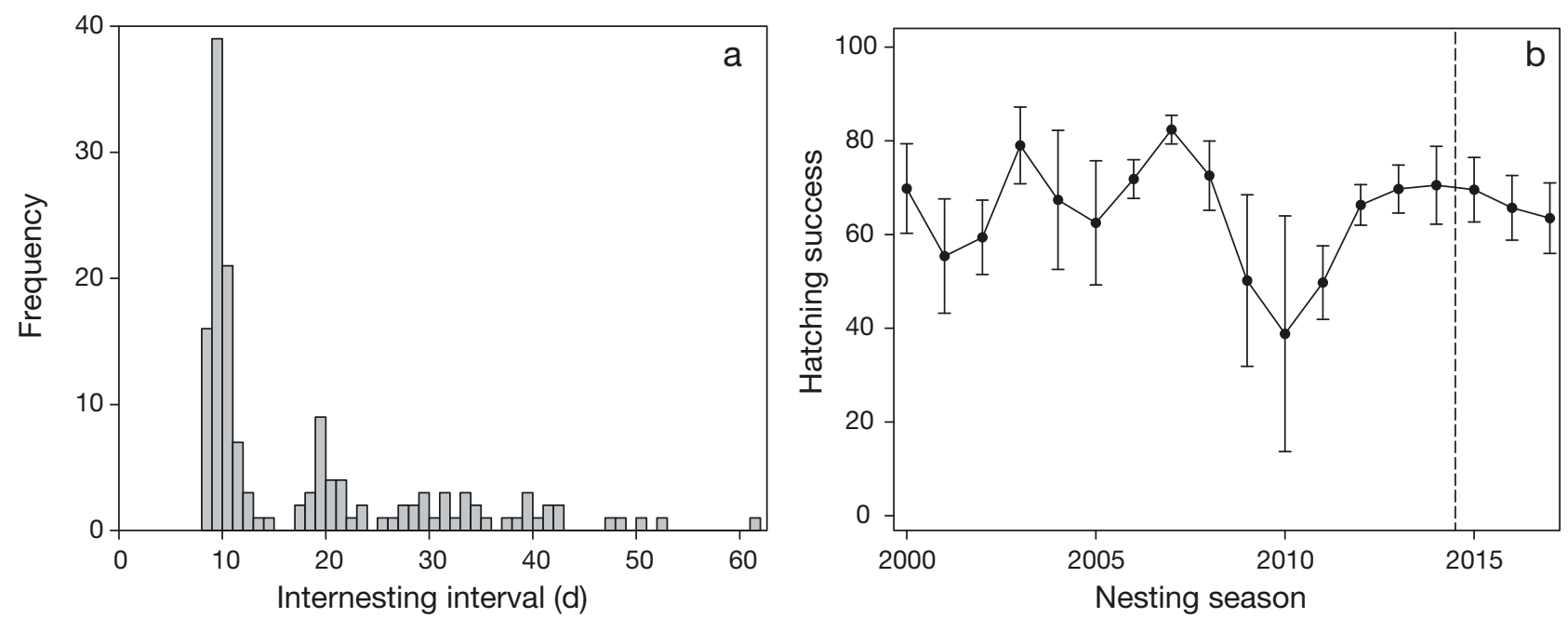

Fig. 5. Reproductive parameters of leatherback turtles in Espírito Santo, Brazil. (a) Observed internesting intervals, 2005-2017 ( $\mathrm{n}=148$ intervals); (b) average hatching success for in situ clutches per nesting season, 2000-2017 (n = 706 clutches). Error bars: $95 \% \mathrm{CI}_{\text {; }}$ dashed vertical line: the mining incident at the beginning of the 2015 season

recorded intervals greater than 15 d likely representing one or more missed nesting events. For turtles showing internesting intervals within the range of 8-15 d ( $\mathrm{n}=88$, or $59.5 \%$ of the total number of recorded intervals), the median interval was $10 \mathrm{~d}$ (mean: $10.4 \pm 1.2 \mathrm{~d}$ ).

\subsection{Remigration interval}

Remigration intervals were obtained from 9 females ( $6.3 \%$ of the 143 tagged females), which contributed $\mathrm{n}=10$ intervals, since 1 female was observed in 3 different seasons. The recorded remigration intervals ranged from 2-17 yr. The most frequent interval was 2 yr $(\mathrm{n}=4)$, followed by $3 \mathrm{yr}(\mathrm{n}=2)$ and 1 record each of 4, 6, 8 and $17 \mathrm{yr}$. The interval of $17 \mathrm{yr}$ likely represents several missed nesting events over some nesting seasons.

\subsection{Hatching success and effects of the mining incident}

The average hatching success for in situ clutches between 2000 and 2017 (18 seasons) was 66.0\% $(\mathrm{SD}=26.2$, range $=0-100, \mathrm{n}=706$ clutches $)$. Annual average hatching success ranged from $38.8 \%$ (in $2010, \mathrm{n}=9$ ) to $82.4 \%$ (in $2007, \mathrm{n}=35$; Fig. 5b). Hatching success was not significantly different between years in the period 2012-2017, which includes 3 seasons $(2012,2013,2014)$ before the mining event and 3 others $(2015,2016,2017)$ following it (Kruskal-Wallis test, $\mathrm{n}=352, \mathrm{p}=0.18$;
Fig. 5b). The mining incident occurred at the peak of the 2015 nesting season; however, no apparent changes in the spatial distribution of leatherback nests on the beach or in the frequency and timing of turtles coming ashore to lay eggs were observed in that season following the incident.

\section{DISCUSSION}

This research provides valuable information regarding the population biology of leatherback turtles in the Southwest Atlantic and highlights the importance of maintaining long-term monitoring to better understand marine turtle ecology and inform conservation. Results were obtained in 4 areas and we discuss them in turn as well as their conservation implications: (1) trends in annual nest numbers and average CCL of the population, (2) trends in the spatial and temporal distribution of nests, (3) reproductive parameters and (4) effects of the mining accident on hatching success.

\subsection{Population trend}

The exponential increase in the annual number of nests in the period 1995-2003 observed by Thomé et al. (2007) appears to be part of a more complex temporal pattern in the annual number of nests (Fig. 2). Despite the generally increasing pattern, the high variability in annual nesting numbers limits a reliable prediction of population growth. The increase in the average annual number of nests from 25.6 in the 
period 1988-1992 to 89.8 in 2008-2017 is encouraging; however, it should be interpreted with caution, since the relatively small annual numbers of nests and small estimated annual number of nesting females-between 15 and $18 \mathrm{yr}^{-1}$ in the last $5 \mathrm{yr}$ of the study period-still make this a population of conservation concern. We currently have no estimate of adult mortality for this population (see e.g. Groom et al. 2017), which hampers predictive abilities regarding population viability. Anthropogenic sources of mortality were suggested to be the main cause of observed population declines in leatherback turtles in the Pacific Ocean (Eckert \& Sarti 1997, Santidrián Tomillo et al. 2017). Low mortality of adults and large juveniles is required to maintain viable marine turtle populations (Crouse et al. 1987).

\subsection{Female size and recruitment}

We hypothesize that the decrease in the CCL, observed mainly from 2011 onwards (Fig. 3), is due to the recruitment of younger and smaller females to the nesting population (Hughes 1996, da Silva et al. 2007, Bellini et al. 2013, Omeyer et al. 2017). The increase in nesting numbers that started around 1995 is possibly a result of egg and adult protection in the area since 1982. This suggests a time lag of ca. $13 \mathrm{yr}$ before the onset of any increase in the leatherback nesting population following the start of protective measures on the beach (as seen in Dutton et al. 2005, where a lag of 12-14 yr was found), which would be consistent with the estimated average leatherback age of maturity of 13-14 yr that has been proposed by Zug \& Parham (1996). However, a more recent study with skeletochronology suggested the age at maturity for leatherback turtles to be 23-27 yr (Avens et al. 2009). Taking into account this last estimate of age at maturity, the wave of smaller females that seems to have recruited to the Espírito Santo nesting population from 2011 on could be the result of increased egg and adult protection since 1982 and/or increased nesting numbers since 1995.

\subsection{Spatial distribution of nests}

The high-density nesting sites were concentrated in the south of the study area (between beach $\mathrm{km} 10$ and $\mathrm{km} \mathrm{60;} \mathrm{Fig.} \mathrm{1a),} \mathrm{and} \mathrm{this} \mathrm{remained} \mathrm{constant}$ across the study period. This region includes both the Comboios Biological Reserve, a protected area, and Povoação (just north of the Doce River mouth), a region currently facing pressure from coastal development and with no designated protected areas status. The mechanisms driving nest site selection by the turtles are not currently understood. Leatherback turtles are known to use an overall nesting area generally wider than that of other sea turtle species (Eckert et al. 2006, Stewart 2007, Almeida et al. 2011). Therefore, despite the importance of the protected area at Comboios, the need exists to expand formal protection to areas to the north of the Doce River mouth (Almeida et al. 2011), since $75.2 \%$ of the recorded nests were observed in this region.

\subsection{Remigration rates}

The recapture rate for remigrant turtles in Espírito Santo ( $6.3 \%$ of individuals tagged) was low when compared to other leatherback turtle rookeries. In an increasing population at St. Croix, US Virgin Islands, the average annual remigration rate in 1977-2001 was $43.5 \%$ (Dutton et al. 2005). In a small population in South Africa, the average annual remigration rate was $33.7 \%$ in 1984-1995 (Hughes 1996). Our low recapture rate could possibly have been influenced by the low encounter rates in our study area, and could also likely have been influenced by a combination of the following factors: first, leatherbacks have high rates of external flipper tag loss - up to $50 \%$ between seasons (Garner et al. 2017). Flipper tags have always been used in Espírito Santo; however, passive integrated transponders (PIT tags), which have never been used there, have proved to be more reliable in generating estimates of remigration intervals and survival (Balazs 1999, Dutton et al. 2005). A second factor is possible high at-sea mortality. Leatherback turtles have a wide oceanic distribution and are prone to interact with fisheries (Fossette et al. 2014), which is considered a major threat to the Brazilian leatherback turtle population (Sales et al. 2008). Dead and injured leatherbacks have been found washed ashore along the Brazilian coast (Barata et al. 2004, Monteiro et al. 2016); genetic studies suggest that some of them could come from the Espírito Santo population (Vargas et al. 2017). Recoveries of females tagged in Espírito Santo are scarce; however, 3 of them were found dead on the Brazilian coast (incidentally captured in fisheries around the Doce River mouth; TAMAR unpubl. data), one in Argentina (Alvarez et al. 2009) and one in Namibia, West Africa (Almeida et al. 2014). Thirdly, turtles tagged in Espírito Santo could be nesting elsewhere. On the main nesting beaches in Brazil, how- 
ever, morning patrols are conducted during the marine turtle nesting seasons, making it unlikely that leatherback tracks would be unnoticed. The points raised here evidence that more research is needed to fully understand remigration patterns for this population.

\subsection{Internesting interval}

The multimodal internesting pattern observed in Fig. $5 \mathrm{a}$, with groups of data located around multiples of the mode of the first group of recorded nesting intervals, is a common feature of sets of internesting intervals obtained through incomplete monitoring of turtles on a nesting site; see e.g. Mortimer \& Carr (1987) and Bellini et al. (2013). In addition to the use of PIT tags for better returns from capture-markrecapture studies, satellite telemetry could provide better insights not only regarding internesting intervals, but also internesting habitat use, remigration and clutch frequency (Tucker 2010, Weber et al. 2013, Rees et al. 2017).

\subsection{Hatching success and possible impacts of the mining incident on leatherback turtles}

The overall hatching success of leatherback turtle nests is low compared to other marine turtle species, and exhibits considerable variability among nesting sites worldwide (Santidrián Tomillo \& Swiggs 2015). At $66 \%$, hatching success in Espírito Santo is higher than that reported for other Atlantic populations. At St. Croix, US Virgin Islands, hatching success was $58.6 \%$ in the period 1982-2010 (Garner et al. 2017). In Matapica, Suriname, the annual average hatching success ranged between 52.7 and $56.0 \%$ in 19992005 (Hilterman \& Goverse 2007). In the previous study by Thomé et al. (2007), the average hatching success for leatherbacks in Espírito Santo in 19942003 was $65.1 \%(\mathrm{n}=185)$, similar to the $66.0 \%$ reported here for the period 2000-2017.

Although the mining incident had catastrophic consequences for both the biodiversity and riparian human communities in the affected areas (Fernandes et al. 2016, Marta-Almeida et al. 2016, Carmo et al. 2017), no significant impact has been observed on leatherback turtle hatching success in Espírito Santo. Given the large scale of this incident, it might be expected that turtles would avoid nesting in the areas around the Doce River mouth, since the coastal water was contaminated with toxic tailings and received a large amount of very turbid river water. However, it seems that the mining incident has caused no noticeable impact on the annual number of nests, as the figures in the years following the event (2016 and 2017) seem to follow a pattern in agreement with those observed in previous nesting seasons (Fig. 2).

Other impacts, however, might take longer to manifest. Contaminated sediments could still find their way into the sand column at concentrations possibly high enough to harm the eggs during incubation. Beach contamination could change the natural composition of the sand in terms of colour and other physical or chemical properties, possibly altering sand albedo and temperature, thus affecting the incubation of eggs. Furthermore, the sea in the region around the Doce River mouth continues (as of November 2018) to receive contaminated water through the river discharge; the effects of that contamination on both hatchlings and adult leatherback turtles while they swim through the surf zone and adjacent coastal waters are unknown but could include passive poisoning of the turtles through sea water. Predictions are hampered by the fact that the levels of contaminants in the region and dispersion mechanisms are still not completely understood (MartaAlmeida et al. 2016).

The reproductive parameters analysed here constitute a baseline for future comparisons when assessing long-term impacts of the burst mine tailing dam on leatherback turtles nesting in Espírito Santo.

\subsection{Future conservation actions}

As with other marine turtle populations (Wallace et al. 2010b, 2013a, Casale \& Heppell 2016), incidental capture in fisheries has been identified as a major threat to the Espírito Santo leatherback turtle population (Thomé et al. 2007, Sales et al. 2008, Almeida et al. 2011). However, other threats also pose challenges for the conservation of this population: coastal development and industrial activities in the region could cause the loss or alteration of important nesting habitats. Possible management plans for the region are being discussed, with the participation of TAMAR and stakeholders, including members of the local villages, local governments, federal and state governmental environmental agencies, universities and institutions managing recovery plans concerning the mining incident. The plans consider different uses of the coastal and marine areas, public policies and the cultural traditions and economic needs of the 
local communities involved. The aim is to establish, in addition to the currently existing Comboios Biological Reserve, an environmentally protected area in a wider region around the Doce River mouth, in a way that would improve conditions for the management and sustainable use of natural resources and the conservation of wildlife. This would be achieved through regulations in the use of coastal land and sea areas and through changes in local fishing practices, aiming to reduce the incidental capture of marine turtles around the nesting area, and also through the development of further economic activities for people that live in the region, such as ecotourism and selected agricultural practices. Measures like these are expected to widen local awareness towards conservation and to improve marine turtle conservation in the area.

Acknowledgements. We thank the numerous people involved in data collection over the several nesting seasons. We also thank Dr. Sam Weber for information concerning regression methods. L.C. acknowledges the support of a Science Without Borders scholarship from the National Council for Scientific and Technological Development (CNPq), Brazil, and the University of Exeter, UK. Additional financial support was granted by the Rufford Foundation and the British Chelonia Group. Fieldwork in Brazil was carried out by TAMAR (the Brazilian Sea Turtle Conservation Programme, co-managed by ICMBio and Fundação PróTAMAR, and officially sponsored by Petrobras) under permit \#41987 from SISBIO (Authorization and Information System on Biodiversity), the research authorization system of the Chico Mendes Institute for Biodiversity Conservation (ICMBio), Brazilian Ministry of the Environment. The manuscript benefited from the detailed input of 4 referees and the Editor. This research was submitted to SISBIO in Brazil (permit no. 47845-3) and approved by the ethical committee at the University of Exeter, UK.

\section{LITERATURE CITED}

Almeida AP, Eckert SA, Bruno SC, Scalfoni JT, Giffoni B, López-Mendilaharsu M, Thomé JCA (2011) Satellitetracked movements of female Dermochelys coriacea from southeastern Brazil. Endang Species Res 15:77-86 Almeida AP, Filgueiras H, Braby R, Tiwari M (2014) Increasing evidence of leatherback migrations from Brazilian beaches to the West African coastline. African Sea Turtle Newsl 1:9-14

Alvarez KC, Diaz L, Almeida AP, Rodriguez Heredia SA (2009) Recuperación de marcas en la costa norte de la província de Buenos Aires, Argentina. In: Prosdocimi L, Carman VG (eds) Libro de resúmenes, IV Jornadas de Conservación e Investigación de Tortugas Marinas del Atlántico Sur Occidental (ASO). Mar del Plata, Buenos Aires, p 166-167

Avens L, Taylor JC, Goshe LR, Jones TT, Hastings M (2009) Use of skeletochronological analysis to estimate the age of leatherback sea turtles Dermochelys coriacea in the western North Atlantic. Endang Species Res 8:165-177
Balazs GH (1999) Factors to consider in the tagging of sea turtles. In: Eckert KL, Bjorndal KA, Abreu-Grobois FA, Donnelly M (eds) Research and management techniques for the conservation of sea turtles. Publication No. 4, IUCN/SSC Marine Turtle Specialist Group, Washington, DC, p 101-109

Baptistotte C, Thomé JC, Bjorndal KA (2003) Reproductive biology and conservation status of the loggerhead sea turtle (Caretta caretta) in Espírito Santo state, Brazil. Chelonian Conserv Biol 4:1-7

Barata PCR, Fabiano FFC (2002) Evidence for leatherback sea turtle (Dermochelys coriacea) nesting in Arraial do Cabo, state of Rio de Janeiro, and a review of occasional leatherback nests in Brazil. Mar Turtle Newsl 96:13-16

*Barata PCR, Lima EHSM, Borges-Martins M, Scalfoni JT, Bellini C, Siciliano S (2004) Records of the leatherback sea turtle (Dermochelys coriacea) on the Brazilian coast, 1969-2001. J Mar Biol Assoc UK 84:1233-1240

Bellini C, Santos AJB, Grossman A, Marcovaldi MA, Barata PCR (2013) Green turtle (Chelonia mydas) nesting on Atol das Rocas, north-eastern Brazil, 1990-2008. J Mar Biol Assoc UK 93:1117-1132

Bezerra DP, Bondioli ACV, Maistro APS, Ebert MB (2014) Occasional leatherback turtle (Dermochelys coriacea) nests: first records in São Paulo state, southeastern Brazil. Mar Turtle Newsl 140:6-8

* Broderick AC, Glen F, Godley BJ, Hays GC (2002) Estimating the number of green and loggerhead turtles nesting annually in the Mediterranean. Oryx 36:227-235

Carmo FF, Kamino LHY, Junior RT, de Campos IC and others (2017) Fundão tailings dam failures: the environment tragedy of the largest technological disaster of Brazilian mining in global context. Perspect Ecol Conserv 15: $145-151$

* Casale P, Heppell SS (2016) How much sea turtle bycatch is too much? A stationary age distribution model for simulating population abundance and potential biological removal in the Mediterranean. Endang Species Res 29: 239-254

* Crouse DT, Crowder LB, Caswell H (1987) A stage-based population model for loggerhead sea turtles and implications for conservation. Ecology 68:1412-1423

* da Silva ACCD, de Castilhos JC, Lopez GG, Barata PCR (2007) Nesting biology and conservation of the olive ridley sea turtle (Lepidochelys olivacea) in Brazil, 1991/ 1992 to 2002/2003. J Mar Biol Assoc UK 87:1047-1056

Dalgaard P (2008) Introductory statistics with $R, 2^{\text {nd }}$ edn. Springer, New York, NY

* Dutton DL, Dutton PH, Chaloupka M, Boulon RH (2005) Increase of a Caribbean leatherback turtle Dermochelys coriacea nesting population linked to long-term nest protection. Biol Conserv 126:186-194

* Dutton PH, Roden SE, Stewart KR, LaCasella E and others (2013) Population stock structure of leatherback turtles (Dermochelys coriacea) in the Atlantic revealed using mtDNA and microsatellite markers. Conserv Genet 14: 625-636

Eckert KL, Wallace BP, Frazier JG, Eckert SA, Pritchard $\mathrm{PCH}$ (2012) Synopsis of the biological data on the leatherback turtle (Dermochelys coriacea). Biological Technical Publication BTP-R4015-2012, US Department of Interior, Fish and Wildlife Service, Washington, DC

Eckert SA, Sarti ML (1997) Distant fisheries implicated in the loss of the world's largest leatherback nesting population. Mar Turtle Newsl 78:2-7 
Eckert SA, Bagley D, Kubis S, Ehrhart L, Johnson C, Stewart $\mathrm{K}$, DeFreese D (2006) Internesting and postnesting movements and foraging habitats of leatherback sea turtles (Dermochelys coriacea) nesting in Florida. Chelonian Conserv Biol 5:239-248

Fernandes GW, Goulart FF, Ranieri BD, Coelho MS and others (2016) Deep into the mud: ecological and socioeconomic impacts of the dam breach in Mariana, Brazil. Nat Conserv 14:35-45

Fossette S, Witt MJ, Miller P, Nalovic MA and others (2014) Pan-Atlantic analysis of the overlap of a highly migratory species, the leatherback turtle, with pelagic longline fisheries. Proc R Soc B 281:20133065

Fuentes MMPB, Gredzens C, Bateman BL, Boettcher R and others (2016) Conservation hotspots for marine turtle nesting in the United States based on coastal development. Ecol Appl 26:2708-2719

Gandu MD, Goldberg DW, Lopez GG, Tognin F (2014) Evidence of leatherback nesting activity in northern Bahia, Brazil. Mar Turtle Newsl 141:10-12

Garner JA, MacKenzie DS, Gatlin D (2017) Reproductive biology of Atlantic leatherback sea turtles at Sandy Point, St. Croix: the first 30 years. Chelonian Conserv Biol 16:29-43

Gerrodette T, Taylor BL (1999) Estimating population size. In: Eckert KL, Bjorndal KA, Alberto Abreu-Grobois F, Donnelly M (eds) Research and management techniques for the conservation of sea turtles. Publication No. 4, IUCN/SSC Marine Turtle Specialist Group, Washington, DC, p 67-71

Groom RA, Griffiths AD, Chaloupka M (2017) Estimating long-term trends in abundance and survival for nesting flatback turtles in Kakadu National Park, Australia. Endang Species Res 32:203-211

*Hays GC, Hobson VJ, Metcalfe JD, Righton D, Sims DW (2006) Flexible foraging movements of leatherback turtles across the North Atlantic Ocean. Ecology 87: 2647-2656

Hilterman ML, Goverse E (2007) Nesting and nest success of the leatherback turtle (Dermochelys coriacea) in Suriname, 1999-2005. Chelonian Conserv Biol 6:87-100

Hollander M, Wolfe DA (1999) Nonparametric statistical methods, 2nd edn. Wiley, New York, NY

Horrocks JA, Stapleton S, Guada H, Lloyd C and others (2016) International movements of adult female leatherback turtles in the Caribbean: results from tag recovery data (2002-2013). Endang Species Res 29:279-287

Hughes GR (1996) Nesting of the leatherback turtle (Dermochelys coriacea) in Tongaland, KwaZulu-Natal, South Africa, 1963-1995. Chelonian Conserv Biol 2:153-158

James MC, Eckert SA, Myers RA (2005) Migratory and reproductive movements of male leatherback turtles (Dermochelys coriacea). Mar Biol 147:845-853

Lindsay RE, Constantine R, Robbins J, Mattila DK, Tagarino A, Dennis TE (2016) Characterising essential breeding habitat for whales informs the development of largescale Marine Protected Areas in the South Pacific. Mar Ecol Prog Ser 548:263-275

Loader C (1999) Local regression and likelihood. Springer, New York, NY

Loebmann D, Legat JFA, Legat AP, Camago RCR, Erthal S, Severo MM, Goes JM (2008) Dermochelys coriacea (leatherback sea turtle) nesting. Herpetol Rev 39:81

Lynch HJ, Fagan WF, Naveen R (2010) Population trends and reproductive success at a frequently visited penguin colony on the western Antarctic Peninsula. Polar Biol 33: 493-503

Machado ABM, Drummond GM, Paglia AP (eds) (2008) Livro vermelho da fauna brasileira ameaçada de extinção. MMA/Biodiversitas, Brasília

Marcovaldi M, Marcovaldi GG (1999) Marine turtles of Brazil: the history and structure of Projeto TAMARIBAMA. Biol Conserv 91:35-41

Marta-Almeida M, Mendes R, Amorim FN, Cirano M, Dias JM (2016) Fundão dam collapse: oceanic dispersion of River Doce after the greatest Brazilian environmental accident. Mar Pollut Bull 112:359-364

*Monteiro DS, Estima SC, Gandra TBR, Silva AP and others (2016) Long-term spatial and temporal patterns of sea turtle strandings in southern Brazil. Mar Biol 163:247

*Mortimer JA, Carr A (1987) Reproduction and migrations of the Ascension Island green turtle (Chelonia mydas). Copeia 1987:103-113

Omeyer L, Godley BJ, Broderick AC (2017) Growth rates of adult sea turtles. Endang Species Res 34:357-371

Patterson DL, Woehler EJ, Croxall JP, Cooper J, Poncet S, Hunter S, Fraser WR (2008) Breeding distribution and population status of the northern giant petrel. Mar Ornithol 124:115-124

* Queiroz HM, Nóbrega GN, Ferreira TO, Almeida LS and others (2018) The Samarco mine tailing disaster: A possible time-bomb for heavy metals contamination? Sci Total Environ 637-638:498-506

R Core Team (2018) R: a language and environment for statistical computing. R Foundation for Statistical Computing, Vienna

Rees AF, Alfaro-Shigueto J, Barata PCR, Bjorndal KA and others (2016) Are we working towards global research priorities for management and conservation of sea turtles? Endang Species Res 31:337-382

* Rees AF, Carreras C, Broderick AC, Margaritoulis D, Stringell TB, Godley BJ (2017) Linking loggerhead locations: using multiple methods to determine the origin of sea turtles in feeding grounds. Mar Biol 164:30

* Robinson NJ, Valentine SE, Tomillo PS, Saba VS, Spotila JR, Paladino FV (2014) Multidecadal trends in the nesting phenology of Pacific and Atlantic leatherback turtles are associated with population demography. Endang Species Res 24:197-206

* Sales G, Giffoni BB, Barata PCR (2008) Incidental catch of sea turtles by the Brazilian pelagic longline fishery. J Mar Biol Assoc UK 88:853-864

Santidrián Tomillo MP, Swiggs J (2015) Egg development and hatchling output of the leatherback sea turtle. In: Spotila JR, Santidrián Tomillo P (eds) The leatherback turtle: biology and conservation. Johns Hopkins University Press, Baltimore, MD, p 74-83

Santidrián Tomillo P, Robinson NJ, Sanz-Aguilar A, Spotila JR, Paladino FV, Tavecchia G (2017) High and variable mortality of leatherback turtles reveal possible anthropogenic impacts. Ecology 98:2170-2179

* Shillinger GL, Palacios DM, Bailey H, Bograd SJ and others (2008) Persistent leatherback turtle migrations present opportunities for conservation. PLOS Biol 6:e171

Soto JMR, Beheregaray RCP, Rebello RAR de P (1997) Range extension: nesting by Dermochelys and Caretta in southern Brazil. Mar Turtle Newsl 77:6-7

Spotila JR, Dunham AE, Leslie AJ, Steyermark AC, Plotkin PT, Paladino FV (1996) Worldwide population decline of Dermochelys coriacea: Are leatherback turtles going 
extinct? Chelonian Conserv Biol 2:209-222

Stewart KR (2007) Establishment and growth of a sea turtle rookery: the population biology of the leatherback in Florida. PhD dissertation, Duke University, Durham, NC

Stokes KL, Fuller WJ, Glen F, Godley BJ and others (2014) Detecting green shoots of recovery: the importance of long-term individual-based monitoring of marine turtles. Anim Conserv 17:593-602

Thomé JCA, Baptistotte C, Moreira LMDP, Scalfoni JT, Almeida AP, Rieth DB, Barata PCR (2007) Nesting biology and conservation of the leatherback sea turtle (Dermochelys coriacea) in the state of Espírito Santo, Brazil, 1988-1989 to 2003-2004. Chelonian Conserv Biol 6: $15-27$

Thomé JC, Martini E, Colman L, Marcondes ACJ and others (2017) A dam disaster in Brazil and its impacts on distant sea turtle beaches. SWOT Rep 12:36-37

Tucker AD (2010) Nest site fidelity and clutch frequency of loggerhead turtles are better elucidated by satellite telemetry than by nocturnal tagging efforts: implications for stock estimation. J Exp Mar Biol Ecol 383:48-55

Vargas SM, Lins LSF, Molfetti É, Ho SYW and others (2017) Revisiting the genetic diversity and population structure of the critically endangered leatherback turtles in the South-west Atlantic Ocean: insights for species conser-

Editorial responsibility: Matthew Godfrey,

Beaufort, North Carolina, USA vation. J Mar Biol Assoc UK 99:31-41Wallace BP, DiMatteo AD, Hurley BJ, Finkbeiner EM and others (2010a) Regional management units for marine turtles: a novel framework for prioritizing conservation and research across multiple scales. PLOS ONE 5:e15465

Wallace BP, Lewison RL, McDonald SL, McDonald RK and others (2010b) Global patterns of marine turtle bycatch. Conserv Lett 3:131-142

Wallace BP, Kot CY, DiMatteo AD, Lee T, Crowder LB, Lewison RL (2013a) Impacts of fisheries bycatch on marine turtle populations worldwide: toward conservation and research priorities. Ecosphere 4:art40

Wallace BP, Tiwari M, Girondot M (2013b) Dermochelys coriacea. The IUCN Red List of Threatened Species 2013: e.T6494A43526147. http://dx.doi.org/10.2305/IUCN.UK. 2013-2.RLTS.T6494A43526147.en (accessed 30 Jan 2019)

炎Weber N, Weber SB, Godley BJ, Ellick J, Witt M, Broderick AC (2013) Telemetry as a tool for improving estimates of marine turtle abundance. Biol Conserv 167:90-96

Wood SN (2017) Generalized additive models: an introduction with R, 2nd edn. CRC Press, Boca Raton, FL

Zug GR, Parham JF (1996) Age and growth in leatherback turtles, Dermochelys coriacea (Testudines: Dermochelyidae): a skeletochronological analysis. Chelonian Conserv Biol 2:244-249

Submitted: August 15, 2018; Accepted: April 12, 2019 Proofs received from author(s): June 17, 2019 